Int. J. Electrochem. Sci., 15 (2020) 2013 - 2026

\title{
Comprehensive Evaluation of a Full-Scale Combined Biological Process for the Treatment of Petroleum Refinery Wastewater using GC-MS and PCR-DGGE Techniques
}

\author{
Xiaoli Dai ${ }^{1,2}$, Chunmao Chen ${ }^{1}$, Yu Chen $^{1}$, Shaohui Guo ${ }^{1, *}$ \\ ${ }^{1}$ State Key Laboratory of Heavy Oil Processing, Beijing Key Laboratory of Oil and Gas Pollution \\ Control, China University of Petroleum, Beijing 102249, China \\ ${ }^{2}$ Environmental Protection Research Institute of Light Industry, Beijing Key Laboratory of \\ Remediation of Industrial Pollution Sites, Beijing 10089, China \\ *E-mail: cupgsh@163.com
}

doi: $10.20964 / 2020.03 .19$

Received: 5 October 2019 / Accepted: 18 December 2019 / Published: 10 February 2020

\begin{abstract}
A full-scale biological process, combining recirculated biofiltration, hydrolysis acidification, anoxic/oxic, anoxic/oxic and membrane bioreactor treatment (RBF-HA-A/O/A/O-MBR), was used for treating petroleum refinery wastewater (PRW). A 25-day field monitoring experiment was conducted to evaluate its running performance. The results showed that the removal efficiencies of $\mathrm{COD}_{\mathrm{Cr}}, \mathrm{BOD}_{5}$, TOC, TN, $\mathrm{NH}_{4}{ }^{+}-\mathrm{N}$ were $96 \%, 100 \%, 98 \%, 56.24 \%$ and $100 \%$, respectively. However, TN was reduced to $61.09 \mathrm{mg} / \mathrm{L}$ from $139.60 \mathrm{mg} / \mathrm{L}$, which was failure to meet the industrial wastewater discharge requirements $(20 \mathrm{mg} / \mathrm{L})$. Gas chromatography-mass spectrometry (GC-MS) analysis showed that the main organic compounds in the influent of the A/O-MBR process were low-concentration and bio-refractory heterocyclic compounds, esters, organic acids, aldehydes and ketones, alkanes, alcohols. It was believed that insufficient effective carbon source limited the nitrogen removal efficiency. The microbial community structural analysis based on the polymerase chain reaction-denaturing gradient gel electrophoresis (PCR-DGGE) technology revealed that the predominant bacteria in different reactors were different. The results showed that the microorganisms of organics degradation were diverse, however, the amount of nitrifying bacteria and denitrifying bacteria were rarely detected or even undetected. Our results suggested that this biological treatment process was effective for organic removal but needs to be improved to increase the TN removal efficiency.
\end{abstract}

Keywords: Petroleum refinery wastewater; Full-scale biological system; RBF-HA-A/O/A/O-MBR; Running performance

\section{$\underline{\text { FULL TEXT }}$}


(C) 2020 The Authors. Published by ESG (www.electrochemsci.org). This article is an open access article distributed under the terms and conditions of the Creative Commons Attribution license (http://creativecommons.org/licenses/by/4.0/). 